\title{
Physicians open to ideas on how to assess and discuss fitness to drive
}

$\mathrm{T}$ here was a time when a visit from Matt Gurwell was a grim event. A former trooper with the Ohio State Highway Patrol, Gurwell would often knock on someone's door to inform them that a family member had died in a car crash. Many of the deceased, he noticed, were elderly drivers who should not have been behind the wheel in the first place.

This prompted Gurwell, after his 24-year career in highway patrol ended, to start Keeping Us Safe, a company based in Painesville, Ohio, that offers programs to help older drivers make a "smooth transition from the driver's seat to the passenger seat" (http://keepingus safe.org).

One item the company provides for free is a "family driving agreement," which, though not legally binding, allows older drivers to designate someone they trust to inform them when they should stop driving or drive with restrictions (http://keepingussafe.org/linked /familydrivingagreement100111.pdf). This document might also prove helpful to doctors, who are often uncomfortable bringing up the topic of driving fitness with older patients.

"It could be a nice way for a physician to start some positive conversation about some day having to retire from driving," says Gurwell.

Physicians indeed appear eager to explore new ideas on how to broach the touchy subject of driving competency with older patients, according to Dr. Paige Moorhouse, a geriatrician and researcher at Dalhousie University in Halifax, Nova Scotia. "One of the challenges is that doctors don't receive a lot of training on how to assess driving ability or how to counsel patients in that regard," says Moorhouse.

In seven of 10 Canadian provinces (all except Nova Scotia, Quebec and Alberta), as well as in all three territories, physicians are legally obligated to

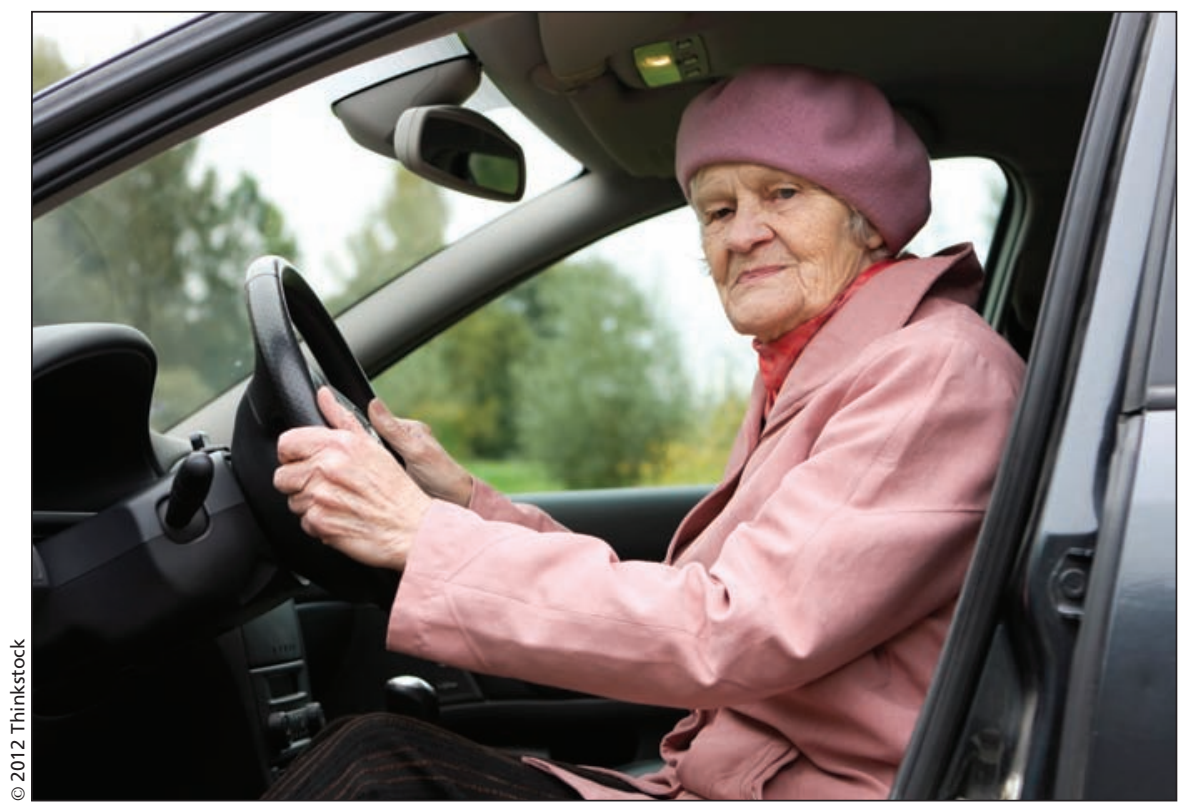

As the population ages, the issue of fitness to drive will be one that doctors have to address more often.

report patients they feel are medically unfit to drive to licensing authorities (www.cma.ca/multimedia/CMA/Content _Images/Inside_cma/WhatWePublish /Drivers_Guide/Section03_e.pdf). Failure to do so can make a physician liable if a patient is subsequently involved in an accident. But some physicians have expressed concern that the scientific standard for making a determination is unclear, while the obligation to assess whether a patient should be allowed behind the wheel puts a strain on the patient-physician relationship (www .cmaj.ca/lookup/doi/10.1503/cmaj.109 $-3822)$.

In a recent paper on barriers to assessing fitness to drive of people with dementia, Moorhouse and several colleagues noted that up to $30 \%$ of the half-million Canadians with dementia still drive, even though their condition increases the odds of having a motor vehicle collision by a factor of eight (Canadian Geriatrics Journal 2011;14:61-5).

"It's a huge problem," says Moorhouse, "More and more people are being diagnosed with dementia as the population ages, and for all those people it will become, at some point, unsafe for them to drive."

The paper was based on a survey of 134 primary care physicians, most of whom stated they routinely discuss driving with patients with dementia but find the conversations uncomfortable, so much so that they sometimes avoid them. Still, doctors appear eager to access more information and resources to assist them in assessing driving fitness and improving communication on the topic with patients.

One thing physicians should do to make these discussions more productive is choose their words carefully, says Gurwell. Many elderly patients have driven for decades without an accident and are proud of their driving records. Implying they are no longer fit to drive and that it's time to "hang up the keys" can be insulting. Instead, he suggests, physicians should use phrases such as "retire from years of successful driving." 
"I appreciate the positive spin they put on it," says Moorhouse. "The driving contracts don't work well in cases of dementia, though, because people have lost insight. Drivers with dementia overestimate their driving skills. There is a big gap between how they perceive their driving skills and how they actually are."

Fortunately, more resources to help the physicians and families of elderly drivers are popping up all the time. For example, Nova Scotia has set up a website tailored to physicians (www .notifbutwhen.ca). Information is presented in a question-and-answer format on the website, which also links to other resources and reviews of medical literature on the topic to "ensure everyone is working with the same information," says Moorhouse.

There are also innovative programs to find alternative modes of transportation for seniors who stop driving, such as the Independent Transportation Network America, which allows people to trade in their cars to pay for rides from volunteers, who in turn accumulate credits toward transportation services they will need in the future (www.itnamerica.org/content /Overview.php.)

It is vitally important that seniors who no longer drive still have a means of transportation, says Gurwell. Otherwise, they can become isolated, fall into depression, miss health care appointments and even spiral downhill physically, possibly leading to a premature death. "It doesn't have to happen that way if the issue is handled properly," says Gurwell, who adds that the burden of having these discussions with older drivers should not be on any one person's shoulders.

"It shouldn't be just the doctor or the family or the minister at church or the neighbour," he says. "It should be everybody." - Roger Collier, CMAJ

CMAJ 2012. DOI:10.1503/cmaj.109-4105 